\title{
Effect of intake level during milk-feeding period and protein content in the post-weaning diet on performance and body composition in growing lambs
}

\author{
T. Manso', A. R. Mantecón², T. Castro ${ }^{3}$ and G. R. Iason $^{3}$ \\ ${ }^{1}$ Departamento de Producción Animal, Facultad de Veterinaria, Universidad Complutense, 28040 Madrid, Spain \\ ${ }^{2}$ Estación Agricola Experimental (CSIC), Apartado de Correos 788. 24080 León, Spain \\ ${ }^{3}$ Macaulay Land Use Research Institute, Craigiebuckler, Aberdeen AB15 8QH
}

\begin{abstract}
The effect of intake level during the milk-feeding period and dietary protein content during the post-weaning period on performance, weight of components of the digestive tract and carcass and non-carcass chemical composition was investigated in 28 Churra lambs. A $2 \times 2$ factorial design was used with two intake levels during the milk-feeding period ( $L_{\text {milk: }}: 0.9$ and $H_{\text {milk: }}: 5 \mathrm{MJ}$ gross energy per $\mathrm{kg} \mathrm{M}^{0.75}$ daily) and two concentrate supplements ( $L_{\text {protein: }}$ : barley grain and $H_{\text {protein: }}$ barley grain plus $200 \mathrm{~g} / \mathrm{kg}$ fish meal) during the post-weaning period. After selecting an initial slaughter group of four 2-day-old lambs, 12 lambs were assigned randomly to each of two intake levels during a 4-week milk-feeding period and given food individually. Four lambs from each intake level were slaughtered at weaning (30 days old) and the remaining 16 were weaned between 30 and 49 days old (weaning period). Eight lambs from each nutritional regimen during the milk-feeding period were further divided into two equal groups and given food individually ad libitum with hay and the post-weaning concentrate, according to the experimental design until the final slaughter weight $\left(20 \mathrm{~kg}\right.$ ) (post-weaning period). $L_{\text {milk }}$ lambs showed a capacity to grow as well as the $H_{\text {milk }}$ during the weaning and post-weaning period and there were no differences $(\mathrm{P}>0.05)$ in dry-matter intake and food conversion ratio among treatments. Before weaning, the weight of the reticulo-rumen was not affected by the intake level during the milk-feeding period. The most affected component of the gastrointestinal tract was the small intestine as proportion of the digestive tract which was lower in $L_{\text {milk }}$ lambs $(\mathrm{P}<0.05)$. At $20 \mathrm{~kg}$ live weight, the relative size of the reticulo-rumen was greater $(\mathrm{P}<0.01)$ and the abomasum $(\mathrm{P}<0.05)$ and large intestine $(\mathrm{P}<0.01)$ were smaller in lambs which were given the $H_{\text {protein }}$ concentrate after weaning. The organic matter apparent digestibility $(O M D, P<0.05)$ and crude protein apparent digestibility ( $C P D, P<0.05)$ of the post-weaning diets was greater in $L_{\text {milk }}$ lambs and the $H_{\text {protein }}$ post-weaning diet was associated with a greater dry-matter apparent digestibility, OMD and CPD when lambs were close to final slaughter weight. At $20 \mathrm{~kg}$ live weight, the proportion of protein in the carcass of $L_{\text {milk }}$ lambs was greater $(\mathrm{P}<0.05)$ than in $H_{\text {milk }}$ lambs. The greater growth of the reticulo-rumen of the $L_{\text {milk }}$ lambs might have increased solid food intake after the milk-feeding period, led to greater CPD of post-weaning diets and had consequences in terms of carcass composition.
\end{abstract}

Keywords: body composition, dietary protein, growth, lambs, milk.

\section{Introduction}

One of the most widely used systems in sheep farming in Mediterranean countries involves the slaughter of lambs of milk-producing breeds at only 4 to 6 weeks of age and a low body weight (approx. 10 to $11 \mathrm{~kg}$ ). The lambs are slaughtered before weaning in order to obtain carcasses which realize the highest price on the meat market since these breeds are early developing and would otherwise not meet market specifications. Possible strategies for production of leaner, heavier carcasses in Churra lambs include the imposition of food restriction followed by compensatory growth and to consider carcass characteristics at slaughter some time after weaning. 
Several studies have shown that the increase in the rate of growth observed following nutritional restriction is a result of greater accretion of protein and a lower deposition of fat during realimentation compared with normal growth (Drew and Reid, 1975; O'Donovan, 1984; Iason et al., 1992; Kabbali et al., 1992). Other studies have shown that fat content of the empty body may be greater or similar in lambs that had been restricted and then realimentated, compared with continuously fed controls (Wilson and Osbourn, 1960; Drouillard et al., 1991). The lack of agreement between studies probably arises from the diversity of factors involved and interactions between the contributing mechanisms.

Nutritional restriction followed by realimentation may lead to changes in size and activity of the gastro-intestinal tract (Ryan, 1990) depending on diet quality (Iason and Mantecón, 1993) and developmental state of the animal (Ørskov, 1992) at the time of treatment. Although these studies have been carried out with meat-producing breeds and during the post-weaning period it is expected that changes in nutritional conditions during the milkfeeding period could lead to changes in the digestive tract which have repercussions during the change from pre-ruminant to ruminant. This in turn would be expected to lead to effects on digestion of the diets during the early post-weaning period and hence compensatory growth during this period.

This study examined the effect of intake level during the milk-feeding period and the dietary protein content during the post-weaning period on performance and body composition of Churra lambs. Digestibility during the post-weaning period, body chemical composition and dimensions of the components of the digestive tract before weaning and at $20 \mathrm{~kg}$ live weight were measured. An understanding of the pattern of growth on performance and body composition during the postweaning period in the Churra sheep could lead to development of feeding strategies to improve the efficiency of use of foods by this important breed for milk production in northern Spain.

\section{Material and methods}

Experimental design

A $2 \times 2$ factorial design was used with two levels of milk intake during the milk-feeding period $\left(\mathrm{H}_{\text {milk }}\right.$ : 1.5 MJ gross energy (GE) per $\mathrm{kg}$ metabolic body weight $\left(\mathrm{M}^{0.75}\right)$ daily and $\mathrm{L}_{\text {milk }}: 0.9 \mathrm{MJ}$ GE per $\mathrm{kg} \mathrm{M}^{0.75}$ daily) and two post-weaning concentrates with different protein levels $\left(\mathrm{H}_{\text {protein }}\right.$ : barley grain plus $200 \mathrm{~g} / \mathrm{kg}$ fish meal and $\mathrm{L}_{\text {protein }}$ : barley grain). Live weight was recorded three times a week throughout the experimental period. The intake was adjusted for the gain in weight during the milk-feeding period and from weaning to $20 \mathrm{~kg} \mathrm{M}$, lambs were given food ad libitum.

\section{Animals and experimental procedure}

Milk-feeding period. Twenty-eight lambs were removed from their mothers at 2 days of age after they had received colostrum. Four animals formed an initial slaughter group (mean live weight, $3.04 \mathrm{~kg}$ ). The remaining 24 were placed individually in pens and randomly assigned to the two levels of intake of milk substitute from days 3 to 30 . Milk replacer was prepared fresh at $190 \mathrm{~g} / \mathrm{kg}$ and given at $09.00 \mathrm{~h}$ and $17.00 \mathrm{~h}$. The composition of milk replacer is shown in Table 1. During the milk-feeding period lambs were only given milk substitute.

Four lambs which had received each level of intake were slaughtered before weaning on day 30 (the preweaning slaughter groups), at the end of the milkfeeding period and the remaining 16 were weaned.

Weaning period. Weaning was carried out between 30 and 49 days of age when the lambs were placed in a group to stimulate the intake of new solid foods. Milk intake for all lambs was reduced to a maintenance level (0.5 MJ GE per $\mathrm{kg} \mathrm{M}^{0.75}$ daily) during the first 7 days of weaning and they had free access to water, lucerne hay and a commercial pelleted concentrate. The composition of the weaning diet, which consisted of barley, soya-bean meal, bran, skimmed milk and mineral and vitamins is shown in Table 1.

Table 1 Composition of the milk replacer and post-weaning diet components

\begin{tabular}{|c|c|c|c|c|c|}
\hline & $\begin{array}{c}\text { Dry } \\
\text { matter } \\
(\mathrm{DM}) \\
(\mathrm{g} / \mathrm{kg})\end{array}$ & $\begin{array}{c}\text { Organic } \\
\text { matter } \\
(\mathrm{g} / \mathrm{kg} \\
\mathrm{DM})\end{array}$ & $\begin{array}{l}\text { Crude } \\
\text { proteint } \\
\text { (g/kg } \\
\text { DM) }\end{array}$ & $\begin{array}{l}\text { Neutral- } \\
\text { detergent } \\
\text { fibre } \\
(\mathrm{g} / \mathrm{kg} \\
\mathrm{DM})\end{array}$ & $\begin{array}{c}\text { t Gross } \\
\text { energy } \\
\text { (MJ } / \mathrm{kg} \\
\mathrm{DM})\end{array}$ \\
\hline $\begin{array}{l}\text { Milk replacer } \\
\text { Weaning diet }\end{array}$ & 973 & 917 & 241 & & $21 \cdot 3$ \\
\hline Lucerne hay & 909 & 904 & 125 & 415 & \\
\hline Concentrate & 918 & 918 & 218 & & $17 \cdot 8$ \\
\hline \multicolumn{6}{|c|}{ Post-weaning diet } \\
\hline Hay & 885 & 938 & 82 & 679 & \\
\hline $\begin{array}{l}\mathrm{H}_{\text {protein }} \\
\text { concentrate }\end{array}$ & 915 & 956 & 294 & & \\
\hline $\begin{array}{l}\mathrm{L}_{\text {protein }} \\
\text { concentrate }\end{array}$ & 907 & 968 & 160 & & \\
\hline
\end{tabular}

+ Crude protein of the milk replacer and solid diet components were calculated as $\mathrm{N} \times 6.38$ and $\mathrm{N} \times 6.25$ respectively. 
Post-weaning period. At 49 days of age the remaining eight lambs from each nutritional regimen during the milk-feeding period were randomly assigned to one of the two post weaning diets. The lambs were placed in individual pens and offered ad libitum a low-quality hay and either of the two concentrates $\left(\mathrm{H}_{\text {protein }}\right.$ and $\left.\mathrm{L}_{\text {protein }}\right)$ until they were slaughtered at $20 \mathrm{~kg}$ live weight (the final slaughter groups). During this period hay and concentrate were offered independently ad libitum and the voluntary intake of each measured daily. The composition of foods used are shown in Table 1.

Apparent digestibility of the post-weaning diets

In the 1st week of the post-weaning period, three lambs in each experimental group were fitted with harnesses for faecal collection. Intake was measured and all faeces collected over 4 days to measure the apparent digestibility of dry matter (DMD), organic matter (OMD) and crude protein (CPD). This procedure was repeated when the lambs were close to slaughter weight.

Slaughter, sample collection and chemical analysis

Lambs were shorn prior to slaughter and their fleece weighed. The mass of bleedable blood was recorded after slaughter and the different compartments of the gastro-intestinal tract (GIT) were separated and their wet mass recorded after emptying and removal of their surrounding fat deposits. The reticulo-rumen, omasum, abomasum, small intestine, large intestine and caecum weights were expressed both in grams and as a proportion of the total weight of the GIT. The skin, feet, head, internal organs and gastrointestinal tract were combined as the non-carcass component. The carcass was weighed warm, cooled and split into two halves. The right carcass half and non-carcass component were minced separately, subsampled, freeze-dried and analysed for ash and protein. Crude protein (CP) was calculated as $\mathrm{N} \times$ 6.25 by the Kjeldahl method and fat content was determined by difference. Energy content was determined using an adiabatic bomb calorimeter. A correction for the weights of blood and fleece was added to the non-carcass component using values from Agricultural Research Council (1980).

\section{Statistical analysis}

All parameters were statistically analysed using standard analysis of variance (ANOVA) with the intake level as a factor. For milk-feeding and weaning period the intake level was entered as a factor into the analysis. For the post-weaning period, the previous intake level of milk and protein content of the diet, together with the interaction of the two, were entered into a two-way ANOVA. Where there were treatment differences $(P<0.05)$, the LSD test (least significant differences) was applied to compare
Table 2 Animal performance during the milk-feeding and weaning period

\begin{tabular}{|c|c|c|c|c|c|}
\hline \multirow[b]{3}{*}{ Treatment† } & & & \multicolumn{3}{|c|}{ Weaning period } \\
\hline & \multicolumn{2}{|c|}{$\begin{array}{l}\text { Milk-feeding } \\
\text { period }\end{array}$} & \multirow[b]{2}{*}{$\begin{array}{c}\text { Initial } \\
\text { weight } \\
\text { (kg) }\end{array}$} & \multirow{2}{*}{$\begin{array}{l}\text { Time to } \\
\text { regain } \\
\text { initial } \\
\text { weight } \\
\text { (days) }\end{array}$} & \multirow{2}{*}{$\begin{array}{c}\text { Daily } \\
\text { weight } \\
\text { gain } \\
\text { (g/ } / \mathrm{kg} \\
\text { initial } \\
\text { weight) }\end{array}$} \\
\hline & $\begin{array}{l}\text { Initial } \\
\text { weight } \\
\text { (kg) }\end{array}$ & $\begin{array}{l}\text { Daily } \\
\text { gain } \\
\text { (g/day) }\end{array}$ & & & \\
\hline $\mathrm{H}_{\text {milk }}$ & 3.06 & 200 & 9.08 & $5 \cdot 3$ & $14 \cdot 7$ \\
\hline $\mathrm{L}_{\text {milk }}$ & $3 \cdot 02$ & 99 & $6 \cdot 03$ & $3 \cdot 1$ & 21.7 \\
\hline & $0 \cdot 656$ & $3 \cdot 0$ & $1 \cdot 213$ & $5 \cdot 07$ & $6 \cdot 22$ \\
\hline Significance & & & & & \\
\hline
\end{tabular}

+ Treatments are defined in material and methods section.

means. The measures of statistical error cited in the tables are the standard error of the means.

\section{Results}

Animal performance

During the milk-feeding period the weight gain in lambs on the high intake level was almost twice that observed in those on the low intake level and thus the live weight at weaning was lower for the lambs on the low feeding level $(P<0.001)$ (Table 2$)$.

During the weaning period there were no significant differences, associated with previous intake level, in intensity and duration of the check in weight gain. When weight gain was expressed as proportion of weight at weaning there was, however, a greater daily gain in the lambs on the lower level of milk intake prior to weaning $(P<0 \cdot 05$, Table 2$)$.

During the post-weaning period there were no differences $(P<0.05)$ in weight gain and dry matter (DM) intake among treatments (Table 3). Daily CP intakes were higher on the high protein postweaning diet throughout the post-weaning period $(P<0.001)$. There were no significant differences in food conversion ratio associated with treatments and there was no significant interaction effect $(P>0.05)$ between the intake level during the milk-feeding period and protein content in the post-weaning diet.

Development of gastro-intestinal tract

Weights of the fat-free GIT and its components for each slaughter group are summarized in Table 4 . The weights of the GIT, reticulo-rumen, abomasum, small intestine and large intestine were all smaller for the initial group than those observed before weaning. The weights of the omasum and caecum, 
Table 3 Effect of nutritional treatment on weight gain, intake and food conversion ratio ( $g$ gain per $g$ dry matter intake) during the post-weaning period

\begin{tabular}{|c|c|c|c|c|c|c|c|c|c|}
\hline \multirow[b]{2}{*}{ Treatmentt } & \multirow{2}{*}{$\begin{array}{l}\text { Initial } \\
\text { weight } \\
\text { (kg) }\end{array}$} & \multirow{2}{*}{$\begin{array}{c}\text { Slaughter } \\
\text { weight } \\
(\mathrm{kg})\end{array}$} & \multirow{2}{*}{$\begin{array}{l}\text { Daily } \\
\text { gain } \\
\text { (g/day) }\end{array}$} & \multicolumn{2}{|c|}{ Dry matter intake } & \multirow{2}{*}{$\begin{array}{c}\text { Forage: } \\
\text { concentrate } \\
\text { ratio } \\
(\mathrm{F}: \mathrm{C})\end{array}$} & \multicolumn{2}{|c|}{ Crude protein intake } & \multirow{2}{*}{$\begin{array}{c}\text { Food } \\
\text { conversion } \\
\text { ratio } \\
(\mathrm{g} / \mathrm{g})\end{array}$} \\
\hline & & & & (g/day) & $\begin{array}{l}\left(\mathrm{g} / \mathrm{M}^{0.75}\right. \\
\text { per day) }\end{array}$ & & (g/day) & $\begin{array}{l}\left(\mathrm{g} / \mathrm{M}^{0.75}\right. \\
\text { per day) }\end{array}$ & \\
\hline $\mathrm{H}_{\text {milk }} \mathrm{H}_{\text {protein }}$ & $10 \cdot 6$ & $21 \cdot 2$ & 210 & 633 & $79 \cdot 4$ & 0.09 & 164 & $20 \cdot 7$ & 0.33 \\
\hline $\mathrm{H}_{\text {milk }} \mathrm{L}_{\text {protein }}$ & $13 \cdot 4$ & $21 \cdot 6$ & 221 & 648 & $75 \cdot 6$ & $0 \cdot 10$ & 99 & $11 \cdot 6$ & $0 \cdot 34$ \\
\hline $\mathrm{L}_{\text {milk }} \mathrm{H}_{\text {protein }}^{\text {protein }}$ & $9 \cdot 1$ & $20 \cdot 0$ & 201 & 636 & $83 \cdot 8$ & 0.07 & 168 & $22 \cdot 0$ & 0.32 \\
\hline $\mathrm{L}_{\text {milk }} \mathrm{L}_{\text {protein }}$ & $8 \cdot 7$ & 18.5 & 186 & 557 & $77 \cdot 5$ & 0.06 & 86 & $12 \cdot 0$ & 0.33 \\
\hline s.e. & 1.94 & $1 \cdot 85$ & $31 \cdot 2$ & $63 \cdot 7$ & $5 \cdot 51$ & 0.060 & $21 \cdot 2$ & $2 \cdot 25$ & $0 \cdot 039$ \\
\hline \multicolumn{10}{|l|}{ Significance } \\
\hline Milk & * & & & & & & & & \\
\hline Protein & & & & & & & $* * *$ & $* * *$ & \\
\hline
\end{tabular}

+ Treatments are defined in material and methods section.

$\ddagger$ Milk: effect of level of milk intake prior to weaning; protein: effect of protein content in the diet.

however, did not differ between initial slaughter and pre-weaning.

Before weaning, GIT, abomasum, small intestine and large intestine weight were greater in lambs with high intake level but the reticulo-rumen, omasum and caecum weights were not affected by intake during milk-feeding period. Lambs on the low intake level during the milk-feeding period showed a lower small intestine weight $(P<0.05)$ relative to GIT than

Table 4 The weights of the fat free gastro-intestinal tract (GIT) and its components expressed in grams and as proportion of empty body weight and GIT respectively in each slaughter group

\begin{tabular}{|c|c|c|c|c|c|c|c|c|c|c|c|c|c|c|}
\hline \multirow[b]{2}{*}{ Treatment +} & \multicolumn{2}{|c|}{ GIT } & \multicolumn{2}{|c|}{$\begin{array}{l}\text { Reticulo- } \\
\text { rumen }\end{array}$} & \multicolumn{2}{|c|}{ Omasum } & \multicolumn{2}{|c|}{ Abomasum } & \multicolumn{2}{|c|}{$\begin{array}{c}\text { Small } \\
\text { intestine }\end{array}$} & \multicolumn{2}{|c|}{$\begin{array}{l}\text { Large } \\
\text { intestine }\end{array}$} & \multicolumn{2}{|c|}{ Caecum } \\
\hline & (g) & $(\mathrm{g} / \mathrm{kg})$ & (g) & $(\mathrm{g} / \mathrm{kg})$ & (g) & $(\mathrm{g} / \mathrm{kg})$ & (g) & $(\mathrm{g} / \mathrm{kg})$ & (g) & $(\mathrm{g} / \mathrm{kg})$ & (g) & $(\mathrm{g} / \mathrm{kg})$ & (g) & $(\mathrm{g} / \mathrm{kg})$ \\
\hline \multicolumn{15}{|l|}{ Initial } \\
\hline \multicolumn{15}{|c|}{$\begin{array}{l}\text { Pre-weaning } \\
\text { slaughter }\end{array}$} \\
\hline $\mathrm{H}_{\text {milk }}$ & $511^{\mathrm{b}}$ & 57 & $65^{\mathrm{b}}$ & $126^{\mathrm{ab}}$ & 10 & $21^{\mathrm{b}}$ & $65^{\mathrm{b}}$ & 128 & $261^{b}$ & $51^{\mathrm{a}}$ & $95^{b}$ & 185 & 14 & $27^{b}$ \\
\hline $\mathrm{L}_{\text {milk }}$ & $344^{c}$ & 60 & $57^{\mathrm{b}}$ & $169^{b}$ & 14 & $40^{\mathrm{ab}}$ & $46^{c}$ & 134 & $157^{c}$ & $45^{b}$ & $59^{c}$ & 172 & 10 & $30^{b}$ \\
\hline s.e. & $53 \cdot 8$ & $4 \cdot 8$ & $11 \cdot 7$ & $31 \cdot 9$ & $5 \cdot 6$ & $19 \cdot 0$ & $9 \cdot 7$ & $28 \cdot 9$ & $25 \cdot 6$ & $34 \cdot 9$ & $11 \cdot 6$ & $20 \cdot 8$ & $2 \cdot 6$ & $7 \cdot 7$ \\
\hline Significance & $* * *$ & & $* * *$ & $*$ & & * & $* * *$ & & $* * * *$ & $*$ & $* * *$ & & & \\
\hline \multicolumn{15}{|c|}{$\begin{array}{l}\text { Final } \\
\text { slaughter } \\
\mathrm{H}_{\text {milk }}\end{array}$} \\
\hline $\begin{array}{l}\mathrm{H}_{\text {protein }} \\
\mathrm{H}_{\text {milk }}\end{array}$ & 1605 & 90 & 760 & 477 & 46 & 28 & 91 & 57 & 515 & 319 & 165 & 102 & 27 & 17 \\
\hline $\mathrm{L}_{\text {protein }}$ & 1506 & 89 & 631 & 420 & 43 & 28 & 110 & 73 & 534 & 353 & 160 & 107 & 28 & 19 \\
\hline $\mathrm{H}_{\text {protein }}^{\mathrm{L}_{\text {milk }}}$ & 1477 & 84 & 720 & 486 & 46 & 31 & 83 & 61 & 461 & 312 & 139 & 94 & 28 & 19 \\
\hline $\begin{array}{l}\mathrm{L}_{\text {milk }} \\
\mathrm{L}_{\text {protein }}\end{array}$ & 1351 & 89 & 573 & 426 & 46 & 34 & 82 & 57 & 452 & 333 & 166 & 122 & 33 & 25 \\
\hline s.e. & $190 \cdot 8$ & $7 \cdot 3$ & $81 \cdot 5$ & $29 \cdot 9$ & $8 \cdot 2$ & $4 \cdot 7$ & $14 \cdot 2$ & $7 \cdot 0$ & $87 \cdot 0$ & $25 \cdot 7$ & $27 \cdot 6$ & 8.59 & $5 \cdot 9$ & $4 \cdot 6$ \\
\hline $\begin{array}{l}\text { Significance } \\
\text { Milk }\end{array}$ & & & & & & & & & & & & & & \\
\hline $\begin{array}{l}\text { Milk } \\
\text { Protein }\end{array}$ & & & & $* *$ & & & 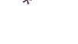 & * & & & & $* *$ & & \\
\hline $\begin{array}{l}\text { Milk } \times \\
\text { protein }\end{array}$ & & & & & & & & & & & & * & & \\
\hline
\end{tabular}

$\overline{a, b, c}$ Means within column with different superscripts differ significantly at $P<0.05$.

+ Treatments are defined in material and methods section.

Milk: effect of level of milk intake prior to weaning; protein: effect of protein content in the diet; milk $\times$ protein: interaction effect between level of milk intake prior to weaning and protein content in the diet. 
Table 5 Apparent digestibility $(\mathrm{g} / \mathrm{kg})$ of the post-weaning diets as affected by previous intake level and protein content

\begin{tabular}{|c|c|c|c|c|c|c|}
\hline Treatmentt & $\begin{array}{l}\text { Dry } \\
\text { matter }\end{array}$ & $\begin{array}{l}\text { Organic } \\
\text { matter }\end{array}$ & $\begin{array}{l}\text { Crude } \\
\text { protein }\end{array}$ & $\begin{array}{l}\text { Dry } \\
\text { matter }\end{array}$ & $\begin{array}{l}\text { Organic } \\
\text { matter }\end{array}$ & $\begin{array}{l}\text { Crude } \\
\text { protein }\end{array}$ \\
\hline $\mathrm{H}_{\text {milk }} \mathrm{H}_{\text {protein }}$ & 802 & 818 & 834 & 828 & 845 & 865 \\
\hline $\mathrm{H}_{\text {milk }} \mathrm{L}_{\text {protein }}$ & 800 & 813 & 701 & 774 & 749 & 624 \\
\hline s.e. & $32 \cdot 4$ & $32 \cdot 2$ & $34 \cdot 8$ & $29 \cdot 9$ & $21 \cdot 1$ & $37 \cdot 8$ \\
\hline \multicolumn{7}{|l|}{ Significancef } \\
\hline Milk & & & & & $* *$ & * \\
\hline Protein & & & $* *$ & $* *$ & $* *$ & $* *$ \\
\hline
\end{tabular}

+ Treatments are defined in material and methods section.

$\ddagger$ Milk: effect of level of milk intake prior to weaning; protein: effect of protein content in the diet.

There was no significant interaction effect between level of milk intake prior to weaning and protein content in the diet.

those on the higher level of intake. The total gastro intestinal tract grew in proportion to empty body weight and the reticulo-rumen, omasum, abomasum, large intestine and caecum weights relative to GIT did not differ between treatments in the milk-feeding period (Table 4).

At the final slaughter, the feeding level before weaning only affected the absolute weight of the abomasum. The GIT weight and its components were similar among slaughter groups. However, the relative size of reticulo-rumen was greater $(P<0.01)$ and the abomasum and large intestine were smaller $(P<0.05)$ in lambs which were given the high protein diet. There was a statistically significant interaction effect between previous intake level and protein content in the post-weaning diet on the relative weight of large intestine $(P<0 \cdot 05$, Table 4$)$.

Apparent digestibility of the post-weaning diets

The DMD, OMD and CPD of post-weaning diets immediately after weaning period and prior to final slaughter weight are shown in Table 5.

There was no influence of the previous intake level on the apparent digestibility of post-weaning diets immediately after the weaning period. However, when digestibility was measured close to $20 \mathrm{~kg}$ live weight, OMD $(P<0.01)$ and $\mathrm{CPD}(P<0.05)$ were greater in lambs given the lower intake before weaning.

The CPD after weaning and DMD, OMD and CPD close to $20 \mathrm{~kg}$ live weight were greater in lambs on the high protein post-weaning diet $(P<0.001)$. The interaction between the two dietary treatments was not statistically significant for any of the digestibility measurements.
Chemical composition of the carcass and non-carcass components

Table 6 shows the composition of the carcass and non-carcass components in initial and pre-weaning slaughter groups. Chemical components are expressed in grams and as a proportion of the total weight of the carcass and non-carcass components.

Before weaning, the proportion of water was greater and the fat and energy content of the carcass and non-carcass were lower in lambs on the lower intake level. The protein content was not affected by the intake level.

At the final slaughter group (Table 7 ), the protein content $(P=0.056)$ and its proportion in the total weight of the carcass $(P<0.05)$ of lambs given the low intake level before weaning was greater than those observed in lambs given the high level of milk intake. On the other hand, animals fed with a high level of protein in the post-weaning concentrate produced carcasses with more energy $(P<0.01)$ and less water $(P<0.05)$ than in lambs supplemented with a low protein concentrate (Table 7 ). The noncarcass chemical components were not affected by the effects studied during the post-weaning period.

\section{Discussion}

Animal performance

Overall performance data throughout the present study were similar to values for Churra lambs reported by Sanz Arias et al. (1977). In this experiment, lambs were weaned gradually thus minimizing the weight loss associated with the weaning process. The time taken to regain weaning weight was inversely related to the intake level during milk-feeding period. A high degree of 
Table 6 Chemical composition of the carcass and non-carcass in initial and pre-weaning slaughter groups

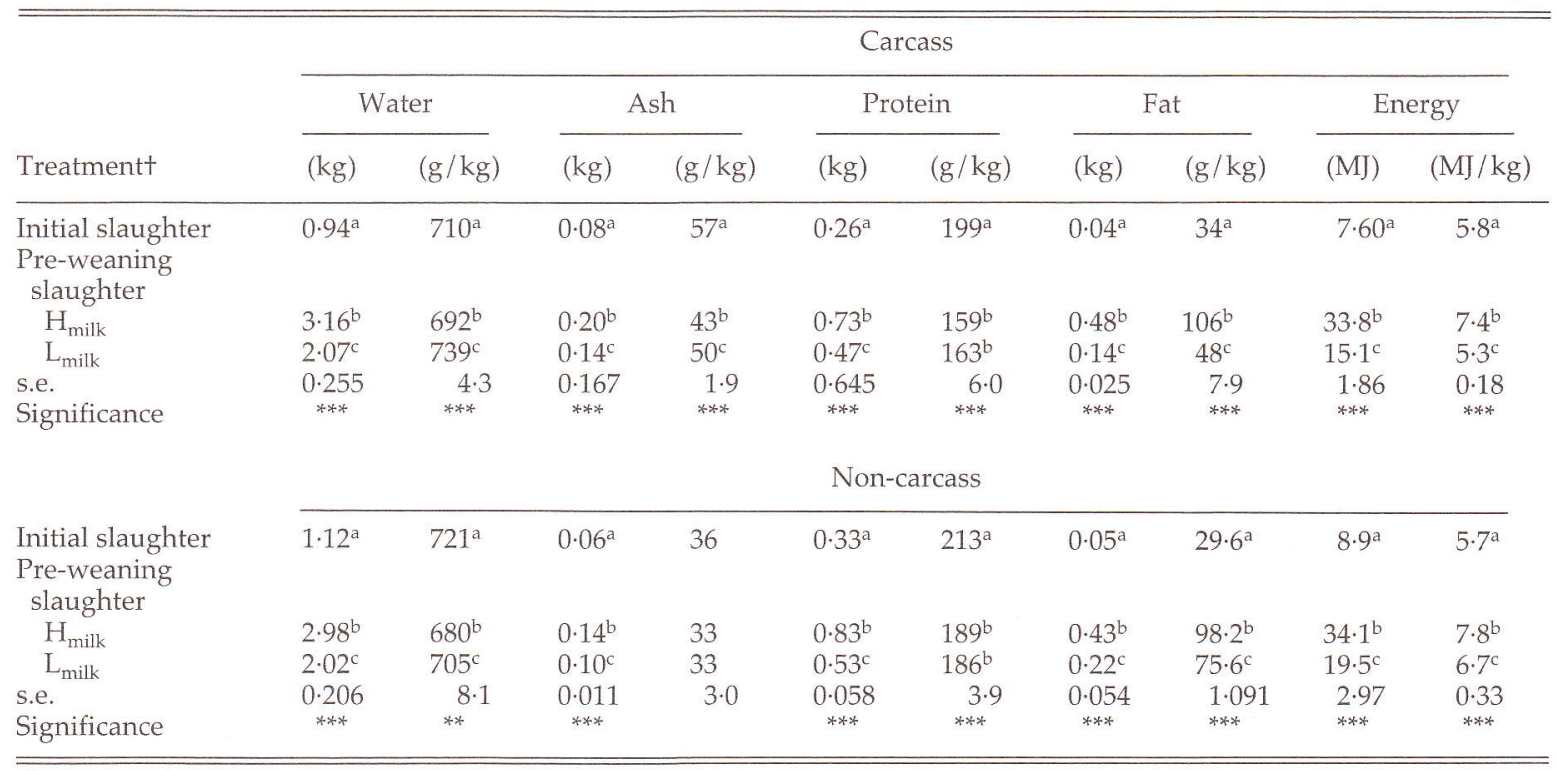

a,b,c Means within column with different superscripts differ significantly at $P<0.05$.

+ Treatments are defined in material and methods section.

individual variability was observed in our data and thus the differences in the average values of the studied traits during the weaning period were not statistically significant. Davies and Owen (1967) showed that restricted milk feeding caused an early acceleration in solid food consumption and had a beneficial effect on animal performance during the post-weaning period. Lambs given the lower intake of food before weaning showed a capacity to grow at least as well as those on the high intake level and as a consequence of the lack of differences in daily DM intake during the post-weaning period the food conversion ratio did not vary among treatments.

Development of digestive tract

Previous studies have reported that at the same body weight, the weight of some components of the GIT of lambs was lower after a period of food restriction (Murray and Slezacek, 1980; Ledin, 1983). In this experiment the total GIT grew in proportion to empty body weight regardless of the amount of milk offered during the milk-feeding period. However,

Table 7 Chemical composition of the carcass in the final slaughter groups

\begin{tabular}{|c|c|c|c|c|c|c|c|c|c|c|}
\hline \multirow[b]{3}{*}{ Treatmentt } & \multicolumn{10}{|c|}{ Carcass } \\
\hline & \multicolumn{2}{|c|}{ Water } & \multicolumn{2}{|c|}{ Ash } & \multicolumn{2}{|c|}{ Protein } & \multicolumn{2}{|c|}{ Fat } & \multicolumn{2}{|c|}{ Energy } \\
\hline & $(\mathrm{kg})$ & $(\mathrm{g} / \mathrm{kg})$ & $(\mathrm{kg})$ & $(\mathrm{g} / \mathrm{kg})$ & $(\mathrm{kg})$ & $(\mathrm{g} / \mathrm{kg})$ & $(\mathrm{kg})$ & $(\mathrm{g} / \mathrm{kg})$ & $(\mathrm{MJ})$ & $(\mathrm{MJ} / \mathrm{kg})$ \\
\hline $\mathrm{H}_{\text {milk }} \mathrm{H}_{\text {protein }}$ & $5 \cdot 60$ & 642 & 0.32 & 36 & $0 \cdot 86$ & 100 & 1.95 & 222 & $87 \cdot 8$ & $10 \cdot 1$ \\
\hline $\mathrm{H}_{\text {milk }} \mathrm{L}_{\text {protein }}$ & $5 \cdot 68$ & 676 & 0.28 & 33 & 0.95 & 113 & $1 \cdot 48$ & 177 & $74 \cdot 6$ & 8.9 \\
\hline $\mathrm{L}_{\text {milk }} \mathrm{H}_{\text {protein }}^{\text {- }}$ & $5 \cdot 38$ & 632 & $0 \cdot 31$ & 36 & $1 \cdot 34$ & 157 & $1 \cdot 49$ & 175 & $89 \cdot 2$ & $10 \cdot 5$ \\
\hline $\mathrm{L}_{\text {milk }} \mathrm{L}_{\text {protein }}$ & $4 \cdot 85$ & 651 & 0.25 & 33 & 1.05 & 142 & $1 \cdot 30$ & 174 & $72 \cdot 5$ & $9 \cdot 7$ \\
\hline s.e. & 0.503 & $17 \cdot 6$ & 0.070 & $7 \cdot 59$ & 0.28 & $34 \cdot 23$ & 0.35 & $34 \cdot 5$ & $9 \cdot 78$ & 0.56 \\
\hline $\begin{array}{l}\text { Significance } \neq \\
\text { Milk }\end{array}$ & & & & & & $*$ & & & & \\
\hline Protein & & * & & & & & & & $*$ & $* *$ \\
\hline
\end{tabular}

+ Treatments are defined in material and methods section.

‡ Milk: effect of level of milk intake prior to weaning; protein: effect of protein content in the diet.

There was no significant interaction between level of milk intake prior to weaning and protein content in the diet. 
the development rate of its components was different between intake levels. The most affected component was the small intestine, the relative size of which decreased as a result of the low intake level. It has been reported that this tissue is highly active metabolically and its atrophication would assist the animal to conserve energy during the restriction (Rompala and Hoagland, 1987; Ferrell et al., 1986). However, in milk-fed lambs rather than viewing this reduction in small intestine as a benefit in terms of energy conservation it is possible that on a milk diet which is easily absorbed, the small intestine simply atrophied because it was not required.

We found no significant differences between treatments before weaning in the weight of the reticulo-rumen either in absolute terms or as a proportion of the GIT. However, there was evidence that the reticulo-rumen of the lower intake group had grown in relative size in comparison with that of the initial slaughter group, whereas that of the high intake group had not.

It has been found that the digestive tract in animals after food restriction needs a period of time to increase its capacity before the food intake is as high as that of control animals (Ryan et al., 1993). However, our results indicated a different effect in early weaned lambs. The intake by lambs during the post-weaning period did not differ between treatments and was probably determined primarily by a combination of the increase in highly fermentable carbohydrates in the diet, which can be rapidly removed from the rumen and by the reticulorumen capacity at weaning, which was also similar between treatments. These results are in agreement with the trend $(P=0.099)$ to a greater daily DM intake in lambs given the high protein post-weaning diet. The extent of digestion varies with the nature and quantity of supplements (Ørskov, 1992). A protein supplementation enhances the degradation rate and facilitates a rapid removal of indigestible food particles and an increase in DM intake. The rate at which the size of the rumen papillae increases is largely a function of the production of volatile fatty acids formed during the fermentation of carbohydrate (Van Soest, 1994) and therefore lambs on the high protein diet showed a greater reticulorumen weight which was inversely related to the abomasum and large intestine weight.

Apparent digestibility of the post-weaning diets

Immediately after the weaning period, there were no differences in apparent digestibility due to previous intake levels. The same diet during the weaning period was probably associated with a similar microbial population and degradation of foods before the reticulo-rumen had reached its mature proportions (Cheng et al., 1991). However, when lambs were close to $20 \mathrm{~kg}$ live weight we observed greater $\mathrm{OMD}$ and $\mathrm{CPD}$ in lambs given the lower quantities of milk substitute before weaning. This may have been due to a better reticulo-rumen function and to a slightly lower forage:concentrate ratio of diet in lambs on the lower level of milk intake.

After weaning, the greater CPD of the high protein diet may be attributed to the relatively constant fraction of faecal nitrogen. The increase of DMD, OMD and CPD at $20 \mathrm{~kg}$ live weight may have been due to the greater amount of rumen degradable protein which would have provided a greater ruminal activity and degradation rate. Barley grain could have been better degraded when a protein supplement was given and therefore greater digestibilities were registered.

Chemical composition of the carcass and non-carcass components

In pre-ruminant animals during growth there was little change in the proportion of protein content in the weight gains made. However the proportion of fat was greater and the amount of water was less in both the carcass and non-carcass components of the higher milk intake groups before weaning. These results are in general agreement with data obtained by Murphy et al. (1994) in crossbred early weaned lambs and support the notion of a priority of accretion of protein over fat when nutrient supply is limited (Greenwood et al., 1996).

The main responses observed in the final slaughter groups were in terms of differences in carcass composition. This study confirms the general conclusions that the effect of a reduction in the level of intake and subsequent ad libitum feeding on carcass composition results in a greater proportion of protein and a lower fat deposition (O'Donovan, 1984). The lack of response in terms of non-carcass composition could be related to a rapid increase in protein deposition soon after ad libitum feeding (Turgeon et al., 1986; Kabbali et al., 1992). The results suggest a different partitioning of nutrient intake during the post-weaning period between carcass and non-carcass components of lambs allowed different levels of intake during the milk-feeding period.

There were few differences between lambs receiving high and low protein diets on body composition. The data presented did not demonstrate clearly a greater need for protein by lambs on the lower level of intake prior to weaning since the high and low level of protein in the post-weaning diets used were apparently satisfactory. There were, however, some 
indications that this might, in fact, have been the case if lower protein levels had been used.

Overall, lambs given the lower quantities of milk showed the same overall intake and growth during the post-weaning period as lambs that had received the high level of intake before weaning. The failure to observe compensatory growth in mass was not entirely unexpected but our results provide some insight into the conditions necessary and mechanisms by which it might occur. It has been previously reported that compensatory growth is not normally observed in lambs that were restricted at very young ages, less than about 3 months (Ryan, 1990). Although our results concur with this expectation we did not observe the permanent stunting predicted by Ryan (1990). Furthermore, it has been proposed that compensatory growth may follow food restriction, if the restriction is applied at a time when it can influence the quantity of fat deposited (Wright et al., 1987). We might have expected the quantities and proportions of fat in the small weaned carcasses of the Churra lambs to be low and relatively insensitive to the level of milkfeeding. In fact the proportions of fat in both the weaned carcass and non-carcass were very much less in the low intake milk-fed group of lambs. Despite this, there was no subsequent compensatory growth in lamb size, hence we can dismiss an effect of the dietary restriction on fat deposition as being a necessary pre-requisite for compensatory growth, at least in Churra lambs.

The main long-lasting effect of the low pre-weaning milk intake was in terms of the persistent effect on carcass composition, namely the higher protein concentration of the carcasses at final slaughter at $20 \mathrm{~kg}$ live weight. This is consistent with the response expected as a result of the qualitative effects of compensatory growth, which usually results in leaner carcasses. Our detailed analysis of the GIT at the various stages of restriction and realimentation showed that the low intake during the milk-fed period led to no consistent changes in the digestive system that could explain this longer-lasting carcass composition effect. The only possible digestive explanation for the effect on final carcass composition is that the greater growth of the reticulo-rumen of the low intake milk-fed group prior to weaning facilitated a greater intake during the weaning period and greater $\mathrm{OMD}$ and $\mathrm{CPD}$ of the post-weaning diet.

In conclusion, restricting the level of intake during the milk-feeding period may offer the possibility of producing leaner carcass of Churra lambs when they are slaughtered at $20 \mathrm{~kg}$ live weight, although further work is required to establish the conditions under which compensatory growth may be used to produce heavier carcasses.

\section{Acknowledgements}

We thank an anonymous referee for critical and helpful comments on the manuscript. This research was funded by the Commission of Science and Technology (Spain) (Project GAN90-0906).

\section{References}

Agricultural Research Council. 1980. The nutrient requirements of ruminant livestock. Commonwealth Agricultural Bureaux, Farnham Royal.

Cheng, K. J., Forsberg, C. W., Minato, H. and Corsterton, J. W. 1991. Microbial ecology and physiology of feed degradation within the rumen. In Physiological aspects of digestion and metabolism in ruminants (ed. T. Tsuda, Y. Sasaki and R. Kawashima). Academic Press, Inc., San Diego.

Davies, D. A. R. and Owen, J. B. 1967. The intensive rearing of lambs. 1 . Some factors affecting performance in the liquid feeding period. Animal Production 9: 501-508.

Drew, K. R. and Reid, J. T. 1975. Compensatory growth in immature sheep. I. The effects of weight loss and realimentation on the whole body composition. Joumal of Agricultural Science, Cambridge 85: 193-204.

Drouillard, J. S., Klopfenstein, T. J., Britton, R. A., Bauer, M. L., Gramlich, S. M., Webster, T. J. and Ferrell, C. L. 1991. Growth, body composition and visceral organ mass and metabolism in lambs after protein or net energy restrictions. Journal of Animal Science 69: 3357-3375.

Ferrell, C. L., Koong, L. J. and Nienaber, J. A. 1986. Effect of previous nutrition on body composition and maintenance energy costs of growing lambs. British Journal of Nutrition 56: 595-605.

Greenwood, P. L., Hunt, A. S., Bell, A. W. and Hermanson, J. W. 1996. Birth size and postnatal nutrition affect body composition in young lambs. Journal of Animal Science 74: (Suppl. 1) 151

Iason, G. R. and Mantecón, A. R. 1993. The effects of dietary protein level during food restriction on carcass and non-carcass components, digestibility and subsequent compensatory growth in lambs. Animal Production 56: 93-100.

Iason, G. R., Mantecón, A. R., Milne, J. A., Sim, D. A., Smith, A. D. M. and White, I. R. 1992. The effect of pattern of food supply on performance, compensatory growth and carcass composition of Beulah and Welsh Mountain lambs. Animal Production 54: 235-241.

Kabbali, A., Johnson, W. L., Johnson, D. W., Goodrich, R. D. and Allen, C. E. 1992. Effects of compensatory growth on some body component weights and on carcass and non-carcass composition of growing lambs. Journal of Animal Science 70: 2852-2858.

Ledin, I. 1983. Effect of restricted feeding and realimentation on compensatory growth, carcass composition and organ growth in lambs. Swedish Journal of Agricultural Research 13: 175-187. 
Murphy, T. A., Loerch, S. C., McClure, K. E. and Solomon, M. B. 1994. Effects of restricted feeding on growth performance and carcass composition of lambs. Journal of Animal Science 72: 3131-3137.

Murray, D. M. and Slezacek, O. 1980. Growth rate effects on some offal components of sheep. Journal of Agricultural Science, Cambridge 95: 241-250.

O'Donovan, P. B. 1984. Compensatory gain in cattle and sheep. Nutrition Abstracts and Reviews, Series B 54: 389-410.

Orskov, E. R. 1992. Development of a functioning rumen. In Protein nutrition in ruminants (ed. E. R. Ørskov and M. Ryle), pp. 5-20. Elsevier Applied Science, London.

Rompala, R. E. and Hoagland, T. A. 1987. Effect of level of alimentation on visceral organ mass and the morphology and $\mathrm{Na}+, \mathrm{K}+$ adenosinetriphosphatase activity of intestinal mucosa in lambs. Journal of Animal Science 65: 1058-1063.

Ryan, J. 1990. Compensatory growth in cattle and sheep. Nutrition Abstracts and Reviews, Series B 60: 653-664.

Ryan, W. J., Williams, I. H. and Moir, R. J. 1993. Compensatory growth in sheep and cattle. I. Growth pattern and feed intake. Australian Journal of Agricultural Research 44: 1609-1621.
Sanz Arias, R., Pelaez, R. and Gonzalez, J. S. 1977. [Milk intake, weaning check, solid food intake and growth from birth until 11 weeks old in lambs fed artificially and weaned at 25, 30, 35 or 40 days old.] Avances en Alimentación y Mejora Animal 18: 125-135.

Turgeon, O. A., Brink, D. R., Bartle, S. J., Klopfenstein, T. J. and Ferrell, C. L. 1986. Effects of growth rate and compensatory growth on body composition in lambs. Journal of Animal Science 63: 770-780.

Van Soest, P. J. 1994. Function of the ruminant forestomach. In Nutritional ecology of the ruminant (ed. P. J. Van Soest), pp. 230-252. Cornell University Press, Itaka and London.

Wilson, P. N. and Osbourn, D. F. 1960. Compensatory growth after undernutrition in mammals and birds. Biological Reviews 35: 324-363.

Wright, I. A., Russel, A. J. F. and Hunter, E. A. 1987. The effects of genotype and post-weaning nutrition on compensatory growth in cattle reared as singles and twins. Animal Production 45: 423-432.

(Received 10 June 1997-Accepted 1 June 1998) 